\title{
Pendidikan Negara \\ Dari Marx ke Stalin \\ Studi Pendekakatan Kritis-filosofis dan heuristika
}

\author{
Oleh: Nabil
}

STIT Al Marhalah Al Ulya Bekasi

Email: anisbata124@gmail.com

..Mendadadak seorang muncul di tepi terowongan dan bekata: "Dilarang membawa kata dari luar"

"kata? Dilarang membawa kata?bapak siapa?"

"Saya pegawai Negara." Ia tak menyebut nama. Hanya nomor.

Wajah orang itu rata. Tingginya rata. Kostumnya tak berwarna...

Goenawan Mohamad

\begin{abstract}
in this century, many people spontaneously label themselves to defend the State because there is an extreme ideology to divide the State in the name of religion, even the events of 1965 returned to the surface as if the State had to apologize for the atrocities and massacres after 1965. Basically, the State was something newly formed from individuals and then groups that have systems, institutions, bureaucracy and usually have sovereignty, both in and out. But in the end it will become absurd when the State is placed above our heads.

The state as an independent institution and has political sovereignty, but as an instrument of oppression and administration that can be used for various purposes by the social classes that control its power. Engels saw the instrumentalist view when he saw that State power was always in the hands of a certain social class - the middle class - who used that power in the interests of maintaining economic and political dominance over other social classes.
\end{abstract}


Nabil

\section{Pendahuluan}

pada abad ini, banyak orang secara spontan melabelkan diri untuk bela Negara karena ada ideologi ektrim untuk memecahbelah Negara atas nama Agama, bahkan peristiwa 1965 kembali ke permukaan seolah-olah Negara harus meminta maaf terhadap kekejaman dan pembantaian pasca 1965. Pada dasarnya, Negara itu sesuatu yang baru terbentuk dari individuindividu kemudian kelompok yang memiliki sistem, lembaga, birokrasi dan biasanya mempunyai kedaulatan, baik dalam maupun keluar. Namun pada akhirnya akan menjadi absurd ketika Negara diletakkan di atas kepala kita.

Ada dua hal yang sering dibicarakan secara mendalam, yaitu perkembangan kesejahteraan dan konsepsi mengenai kedaulatan Negara. Negara dalam pengertian sekarang boleh dikatakan merupakan gejala yang relatif baru. Di zaman Yunani kuno sebenarnya sudah disadari arti pentingnya Negara bagi manusia, tetapi bentuk Negara yang ada dalam pandangan mereka tidak lebih luas dari Negara-negara kota (city state). Manusia memerlukan Negara untuk mencapai perkembangan tertinggi dalam peradabannya. Manusia tidak di bawah Negara, namun merupakan bagian integral dari Negara, karena itu seharusnya tidak boleh ada perbedaan antara kepentingan umum dan kepentingan perseorangan. Aristoteles pernah berkata dalam karya besarnya "politics" bahwa manusia adalah makhluk politik yang dapat mencapai apa saja yang diinginkan sepanjang mereka tetap sadar bahwa mereka hidup dalam satu Negara. Untuk mencapai tujuan-tujuan itulah manusia harus diberi kesempatan untuk kemampuan moral dan intelektualnya secara penuh.

Kesejahteraan Negara bukan berdasarkan ekonomi semata dalam pengertian yang lebih modern, namun dalam kerangka kesejahteraan dalam masyarakat Eropa mengetengahkan satu kebijakan baru yang dikenal dengan 
istilah Merkantilisme $^{1}$. Politik semacam ini mencoba menempatkan superioritas Negara dalam bidang politik dan ekonomi di atas saingansaingannya.

Setelah perkembangan Negara mencapai puncaknya, konsep kedaulatan Negara mulai diperdebatkan orang. Istilah kedaulatan menunjuk pada kekuatan absolute dan final dalam satu masyarakat tertentu. Dalam kenyataannya, banyak bentuk kedaulatan yang bisa dibedakan satu sama lain, misal ada kedaulatan titular sebagaimana dimiliki oleh mahkota kerajaan Inggris, kedaulatan hukum yang di dalamnya setiap orang ataupun kelompok berhak menentukan dan mengatur fungsi-fungsi pemerintahannya sendiri atau kedaulatan politik dan konstitusional di mana masing-masing mempunyai kekuasaan penuh sebagaimana yang berlaku di Amerika Serikat.

Gagasan kedaulatan sebenarnya sudah mulai dibicarakan oleh Aristotees dalam bukunya Poltics, bahwa kekuasaan tertinggi dan sah Negara bisa saja dipegang oleh satu tangan, beberapa orang, atau malahan banyak orang. Dalam tradisi Romawi kedaulatan ada di tangan rakyat, kendatipun dalam pelaksanaannya didelegasikan kepada raja.

Menganalisis pemikiran Marx tentang Negara ${ }^{2}$, Hegel akan sepakat dengan Marx bahwa masyarakat sipil akan terancam krisis jika dibiarkan berjalan sendiri. Namun Hegel berpendapat bahwa Negara dapat dan harus menjamin kepentingan umum daripada kepentingan-kepentingan partikular yang saling bersaing di dalam masyarakat, dan dengan demikian mencegah resiko yang mengancam sistem. Dalam tulisan-tulisan yang lebih awal, Marx telah mengkritik pandangan tentang Negara atas nama demokrasi yang radikal. Menurut Marx, pemerintahan harus dijalankan oleh dan untuk rakyat,

\footnotetext{
1. Strurt Gerry Brown, State, dalam Encyclopedy International., (New York: Glorier, 1970)

2 . Hans Fink, Filsafat Sosial, Dari Feodalis Hingga Pasar Bebas, diterjemahkan dari judul asli:Social Philosophy, Methuen \& Co. Ltd, London dan Methuen \& Co. New York, 1981, Penerjemah: Sigit Djatmiko, (Yogyakarta: Pustaka Pelajar, Cet. I, 2003), hlm. 143-146
} 
dan tidak boleh dibiarkan berada di tangan birokrasi yang posisisnya lebih tinggi daripada masyarakat. Dalam masyarakat berkelas, menurut Marx Negara adalah alat dari kelas berkuasa, kendati Negara terkesan sebagai semacam penengah yang netral di antara berbagai kepentingan yang saling bersaing. Kemudian dalam masyarakat kapitalis, Negara adalah alat kelas pemilik modal.

Di dalam Manifesto Komunis, Mark menganggap Negara sebagai alat kekuasaan kelas dan membawa kita pada kesimpulan yang tak dapat dihindari lagi bahwa proletariat tidak dapat menggulingkan borjuis tanpa terlebih dahulu merebut kekuasaan politik, tanpa memperoleh kekuasaanunggul politik, tanpa mengubah Negara menjadi proletariat yang terorganisir sebagai kelas yang berkuasa, dan bahwa Negara proletariat ini akan mulai melenyap segera setelah ia memperoleh kemenangan, karena Negara adalah tidak perlu dan tidak dapat ada dalam suatu masyarakat dimana tidak terdapat antagonism kelas.

Negara dalam pengertian $\mathrm{Hegel}^{3}$, memang sebuah struktur di mana yang universal menemukan wujudnya. Negara adalah Negara ilahi sebagaimana ia ada di atas bumi. Tapi bagi saya, Marx lebih benar: "Negara" tak pernah bisa jadi wadah bagi siapa saja, kapan saja. "Negara" selalu bersifat "partikular", hanya merupakan alat kekuasaan kelas tertentu di ruang dan waktu tertentu. Bukan sesuatu yang kekal. Bagi para pemikir setelah Marx, bahkan "Negara" bukan sesuatu yang siap. Ia sebuah proyek untuk menertibkan situasi yang berlipat-lipat ragamnya, situasi yang, kata Badiou, mirip "anarki sejati". Dalam "Negara" sebagai proyek penertiban, unsur dan bagian-bagian diklasifikasikan, dan diberi sebutan, posisi, dan peran. Mungkin ia tampak utuh, tapi dalam tersusunnya sistem itu selalu ada

\footnotetext{
${ }^{3}$. G.W.F. Hegel, Filsafat Sejarah, judul asli: The Philosophy of History, Penerjemah: Cuk Ananta Wijaya (Yogyakarta: Pustaka Pelajar, Cet. III, 2007), hlm. 54
} 
"bagian yang tak punya bagian". Dengan itulah sebuah komunitas politik, sebuah "Negara", menjadi-sesuatu yang tak stabil dan mengandung sengketa.

Kekuasaan Negara yang tersentralisasi yang khas bagi masyarakat adanya absolutism. Dua lembaga paling karateristik dari Negara adalah birokrasi dan tentara tetap. Birokarsi dan tentara tetap adalah parasit yang dilahirkan oleh antagonism internal yang mengoyak masyarakat, tetapi juga parasit yang menyumbat semua pori-pori yang vital. Menurut pandanganag Oportunisme ala Kaustky bahwa Negara adalah organism parasit sebagai sifat yang khas dan luar biasa dari anarkisme.

Perlu diketahui apa yang dimsksud dengan Negara. Negara memiliki dua pengertian. Pertama, Negara diartikan sebagai organisasi di suatu wilayah yang mempunyai kekuasaan teringgi yang sah yang ditaati oleh rakyat. Kedua, Negara diartikan sebagai kelompok sosial yang menduduki wilayah atau daerah tertentu yang diorganisasi di bawah lembaga politik dan pemerintah yang efektif, mempunyai kesatuan politik, berdaulat sehingga berhak menentukan tujuan nasionalnya.

Menurut Franz Magnis-Suseno dalam buku Etika Politik (1987) ada dua pengertian Negara. Pertama, Negara adalah masyarakat atau wilayah yang merupakan satu kesatuan politis. Kedua, Negara adalah lembaga pusat yang menjalin kesatuan politis itu, yang menata dan dengan demikian menguasai wilayah itu. Atas dasar itulah penafsiran Marx yang ulung berpendapat bahwa kekuasaan atas Negara harus direbut melalui revolusi, sebab para pemilik modal yang didukung oleh Negara tidak akan melepaskan kekuasaannya atas alat-alat produksi secara sukarela. Revolusi yang benar hanya bisa sukses apabila didasari pada teori yang benar, kaum buruh tidak menguasai teori secara benar, sehingga harus dipimpin oleh cendekiawan revolusioner dalam satu partai pelopor yabg didasarkan pada teori Marxian yang benar. Itulah yang disebut dengan dictator proletariat. 
Nabil

Dari seluruh uraian diatas dapat ditarik suatu analisis. Penulis berusaha melakukan penelitian Pemikiran Marx tentang Negara sehingga sebuah teori Negara sampai bisa diwujudkan pada masa Lenin dan Stalin.

\section{Teori Negara Marx dan Engels}

Dalam teori Marx bisa ditemukan berbagai tulisan Marx. Dalam The Eighteen Brumaire of Louis Bonaparte (1852) Marx menggambarkan Negara Prancis sebagai sebuah kekuasaan eksekutif yang dilengkapi dengan organisasi militer dan birokrasi. Dalam The Civil War in France (1871), ia menyebutkan Negara yang sama dalam konteks "centralized state power with its ubiquitous organs of standing army, policy, bureaucracy, clergy, and justice" (hlm. 402). Sementara dalam Critique of the Gotha Programme (1875) perhatian Marx ditujukan kepada Negara Prussia yang digambarkan sebagai a police-guarded military despotism, embellishedwith parliamentary from, and bureaucratically carpentered. (hlm. 29-30). Di lain pihak, Engels mendefinisikan Negara dengan cara tidak jauh berbeda dengan Marx. Dalam On the Origins of Family, Private Property, and the State ia menggambarkan Negara sebagai sebuah organisasi sosial berdasarkan wilayah territorial dengan wewenang mengoperasikan kekuatan militer, menarik pajak dan menjalankan administrasi.

Seperti yang dijelaskan di atas, pada mulanya pemahaman Marx tentang Negara mencerminkan pengaruh filsafat Hegelian. Dalam tulisantulisan awalnya, Marx belum mengembangkan teori Negara berdasarkan kelas atau konsep Negara kapitalis. Diantaranya memberlakukan Negara sebagai sistem dominasi politik yang bersifat abstrak yang menolak sifat sosial manusia dan mengasingkan manusia dari kehidupan public. Ia menganggap para pejabat pemerintah sebagai actor-aktor yang memperesentasikan kepentingan pribadi dan melihat upaya birokrasi 
menguasai kekuasaan Negara sebagai bagian dari proses memperbesar kekuasaan para birokrasi. Dalam The Condition of the Working Class in England (1845) Engels menjelaskan kekuasaan Negara mempresentasikan kekuasaan property yang secara fisik ia identikkan dengan middle class dan atau bourgeoisie. Hanya saja Engels tidak mengembangkan teori Negara berdasarkan kelas.

Salah satu sentral teori Marx dan Engels tentang Negara adalah pengaruh economy base terhadap keseluruhan bangunan political superstructure. Menurut pandangan struktural ini, Negara mencerminkan economic base sebuah masyarakat. Intervensi yang dilakukan Negara bertujuan untuk memenuhi kepentingan produksi yang bertujuan menghasilkan surplus value dan hubungan produksi merupakan fondasi dasar yang menentukan sistem politik dan kesadaran sosial (Marx, 1859). Dalam The German Ideology (1845) Marx dan Engels menjelaskan perkembangan Negara berjalan seiring dengan pembagian kerja sosial di masyarakat yang melahirkan kelas dominan dan kelas subordinan. Menurutnya, konflik politik dalam Negara (antara partai yang berbeda, antara politisi, atau antara birokrat) hanyalah sebuah ilusi, karena konflik yang sebenarnya berlangsung pada level antagonis antara kelas yang dominan dengan kelas subordinan.

Argumentasi tentang base-superstructure menimbulkan kesan reduksionisme dan determinisme ekonomi. Pada kenyataannya, Marx dan Engels menjelaskan bahwa sistem produksi yang berbeda akan menghasilkan bentuk Negara yang berbeda dan perubahan metode produksi dan perimbangan kelas menentukan perubahan sifat kekuasaan Negara. Dalam masa transisi dari feodalisme menuju kapitalisme, misalnya, sistem produksi memerlukan kehadiran Negara yang kuat. Sebaliknya, setelah memasuki fase kapitalisme penuh berdasarkan prinsip-prinsip laissez-faire sistem produksi menghendaki Negara yang lemah dan tidak banyak melakukan campur 
tangan dalam urusan-urusan ekonomi. (marx, 1858; Engels, 1878). Tetapi teori Marx dan Engels tidak sepenuhnya tentang Negara bersifat reductionist dan mono determinist karena selain argumntasi base superstructure kedua pendapat ini juga mengomentari teori Negara instrumentalis. Dalam teori ini Negara merupakan refleksi kepentingan kelas sosial. kelas sosial itu sendiri bukan merupakan struktur yang bersifat monolitik, melainkan terdiri dari kepentingan-kepentingan yang bertolak belakang. Konsekuensinya, Negara instrumentalis tampil dalam bentuk yang lebih dinamik mengikuti perubahanperubahan yang selalu berlangsung dalam konflik kelas.

Secara garis besar teori instrumentalis tidak melihat Negara sebagai institusi yang independen dan memiliki kedaulatan politik, tetapi sebagai instrument penindasan dan administrasi yang bisa digunakan untuk berbagai tujuan oleh kelas-kelas sosial yang mengontrol kekuasaannya. Engels melihat pandangan instrumentalis ketika melihat kekuasaan Negara selalu berada di tangan kelas sosial tertentu -middle class- yang menggunakan kekuasaan tersebut untuk kepentingan mempertahankan dominasi ekonomi dan politik atas kelas-kelas sosial lainnya.

Dalam mengembangkan pendekatan intrumentalis Marx dan Engels memberika perhatian yang cukup besar terhadap analisis perjuangan kelas. Kedua pemikir ini menjelaskan tentang proses polarisasi yang ditimbulkan pertumbuhan kapitalisme produksi yang membelah masyarakat menjadi kelas pemilik modal dan kelas proletar. Perjuangan kelas ditandai dengan control kelas pemilik modal atas kekuasaan Negara yang digunakan untuk menindas kelas proletar. Marx dan Engels menyebutkan dengan fraction dalam kelas sosial, hubungan antara fraksi-fraksi yang berbeda dalam satu kelas sosial dan kemungkinan-kemungkinan bagi aliansi kelas.

Marx dan Engels membahas teori Negara secara otonom sejak The German Ideology, Negara muncul dan berdiri di atas antagonism kelas, agar 
Negara memiliki kemampuan untuk mengelola kepentingan umum gentile society. ${ }^{4}$ Sedangkan Engels (1884) menulis kehadiran Negara diperlukan untuk menengahi konflik yang pasti terjadi antar-kelas sosial yang berbeda dan mengelola konflik tersebut dalam batas-batas yang dapat diterima dalam sebuah tertib sosial. Bentuk paling ekstrim dari Negara otonom bisa ditemukan dalam kekuasan otoriter Louis Bonaparte. Studi sejarah atas kekaisaran Prancis kedua ini, Marx berusaha menjelaskan karakter dasar tipe Negara yang dibentuk Bonaparte melalui sebuah kudeta. Kesan kudeta yang dilakukan Bonaparte berhasil mendirikan sebuah Negara yang sepenuhnya otonom terhadap kontrol kelas sosial dominan. Penjelasan tersebut cendrung mengembalikan pengaruh kerangka berpikir Hegelian yang menekankan pemisahan state-civil society dan public-private. Sebaliknya Marx menegaskan "the state power does not hover in mid-air. Ia menjelaskan sekalipun independen, Bonaparte secara terus-menerus berupaya menampilkan dirinya sebagai representasi kelas sosial tertentu. Pada mulanya, Bonaparte mengidentikkan dirinya sebagai pelindung kepentingan para petani kecil pemilik tanah. Ia jua membenarkan kudeta ya ia lakukan sebagai upaya mengembalikan bourgeois order, dan karenanya mendefinisikan kekuasan yang dimilikinya sebagai representasi kepentingan kelas menengah. Akan tetapi bagi Marx, meskipun Bonaparte berusaha keras menempatkan dirinya sebagai "the chief of society" yang mengatasi kepentingan semua kelas sosial, dalam praktiknya Bonapartisme bertujuan mendukung dan mempertahankan orde sosial borjuis yang memungkinkan keberlangsungan dominasi ekonomi dan politik para pemilik modal atas pekerja (Miliband, 1973).

\footnotetext{
${ }^{4}$. Gentile secara literasi bisa diartika sebagai seseorang atau kelompok sosial tertentu yang memiliki status sosial yang tinggi. Pada masa peralihan dari feodalisme ke kapitalisme di Inggris, Prancis, dan Jerman yang masuk dalam katagori gentile society biasanya pada pemilik property rights, seperti tuan tanah dan borjuis.
} 
Nabil

\section{Konsepsi Negara menurut Hegel}

Negara dalam pemikiran Hegel merupakan Roh Absolut (Great Spirit atau Absolute Idea). ${ }^{5}$ Karena itu, Negara bersifat Absolut yang dimensi kekuasaannya ,elampaui hak-hak transcendental individu. Mengikuti logika dialektika Hegel, Negara merupakan suatu tahap perkembangan ide mutlak. Perkembangan ini ditandai oleh proses gerak dialektis yang terjadi antara tesis-anitesis yang kemudian melahirkan sintesis. Dari sintesis ini kemudian muncul lagi tesis-antitesis dan seterusnya. Proses dialektik ini baru berakhir setelah tercapainya ide mutlak.

Gagasan "Roh Absolut" Hegel dipengaruhi oleh pemikiran Kristiani, yakni tentang roh kudus dalam doktrin trinitas. Sebagai sesuatu yang suci (sakral), Hegel pun melihat Negara sebagai organ politik yang suci pula. Hegel mensakralisasi Negara. Dia melihat sepak terjang Negara sebagai "derap langkah Tuhan" di bumi, the state is divini idea as it exist on earth. ${ }^{6}$ Tentunya hegel mempunyai konsekuensi terhadap gagasannya tentang kekuasaan Negara, yaitu bahwa kekauasaan entah itu raja, fuhrer, presiden atau apapun namanya, adalah akal impersonal dan perwujudan kemauan kolektif yang menjelma menjadi manusia. Pemimpin Negara bisa saja mendengarkan suara-suara wakil rakyat tetapi tidak mengikat karena kekuasaan pada Negara mutlak. $^{7}$

Berbeda dengan Marx yang melihat Negara sebagai alat kekuasaan, Hegel justru berpendapat bahwa Negara itu bukan merupakan alat melainkan tujuan itu sendiri. Karena itu, dalam logika Hegel, bukan Negara yang harus

\footnotetext{
5. Ahmad Suhelmi, Pemikiran Politik Barat: Kajian Sejarah Perkembangan Negara, Masyarakat dan Kekuasaan., (Jakarta: Gramedia Pustaka Utama, 2001), hlm. 258-260.

6. Dikutip dalam Andrew Hacker, Political Theory, Philosophy, Ideology, Science., (New York: The Mcmillan, 1969), hlm. 445

7. A. Pelcynski, Hegel's Political Philosophy, Problems and Perspective, (Cambridge University Press, 1971)
} 
mengabdi kepada rakyat atau individu maupun golongan masyarakat melainkan sebaliknya, merekalah yang harus mengabdi dan diabadikan demi Negara. Mereka harus menjadi abdi Negara. Hegel berdali agar kebaikan dan kesejahteraan masyarakat itu sendiri. Hegel berpendapat juga bahwa Negara bersifat unik karena ia memiliki logika, nalar sistem berpikir dan berprilaku tersendiri yang beda dengan yang dimiliki organ politik apa pun. Karena itu bisa saja Negara menegasi kebebasan atau kemerdekaan individu dengan asumsi bahwa individu tidak memiliki makna dalam totalitas Negara. Ia harus lebur dalam kekuasaan Negara. Tetapi perlu diingat bahwa ini bukan berarti Hegel tidak mengakui eksistensi kebebasan individu. Ia mengakuinya, meski anehnya kebebasan tidaklah harus selalu berkonotasi demokrasi.

\section{Konsepsi Negara menurut Marxis}

Penulis menggunakan istilah marxis kalau penekanannya pada buah pikiran, sedangkan komunis kalau penekanannya pada kekuatan sosial politik. Filsafat historis materialism menjadi kata kunci dari pemikiran Marx. Dalam mengkritik metode dialektika Hegel, Marx memahami proses sejarah sebagai rentetan konflik (antagonism) dalam wujud revolusi di antara dua kelas yang berlawanan (tesis melawan anti-tesis). Buah dari revolusi itu menghasilkan kelas baru (sintesis). Demikianlah proses dialektika terus berjalan sepanjang masa. Begitu tumbuh orde sosial-ekonomi yang baru, maka terjadilah konflik dengan kelas hasil sintesis. Maka terjadilah revolusi pula. Kekuatan baru (anti-tesis) melabrak kekuatan lama (tesis) yang berupaya mempertahankan status-quo.

Teori pertentangan kelas itu dilihat dari sejarah abad pertengahan di Eropa (antara zaman kalasik dengan Renaissance, dari abad ke-5 M sampai $1500 \mathrm{M})$. golongan tukang tumbuh menjadi saudagar dan industriawan, yang kemudian disebut kelas borjuis lalu menjadi anti-tesis dari kelas feudal (tesis) 
sebagai kelas penguasa. Benturan kelas borjuis dengan kelas feudal tersebut membuahkan sintesis berupa kapitalis. Selanjutnya tanpa didukung oleh fakta sejarah Marx berspekulasi bahwa proses dialektis berlanjut terus dengan adanya kelas baru, yaitu kelas proletar, sebagai anti-tesis dari kelas kapitalis. Revolusi kelas proletar akan menghasilkan masyarakat tanpa kelas, dan inilah menjadi akhir sejarah pertentangan kelas menurut spekulasi Marx. Kemudian Marx berangan-angan lebih jauh lagi, yaitu masyarakat tanpa kelas nanti berjalan tanpa Negara, semua orang bekerja sesuai dengan kemampuannya dan mendapatkan sesuai dengan kebutuhannya. Untuk itu diperlukan sebuah pemimpin yang disebut dictator proletariat. Menurut Marx , Negara harus bubar, karena Negara tidak lain dari alat kelas atas untuk menekan kelas bawah, yaitu alat kelas feudal menekan kelas borjuis dan alat kapitalis menekan kelas proletar.

Hakikat Negara telah disebutkan dalam bukunya Manifesto Komunis kemudia ia sangkal sendiri setelah mempelajari pengalaman Komune Paris. Semula Marx beranggapan, bahwa kaum proletar memegang tampuk kekuasaan, mereka harus mengambil kendali alat-alat yang ada lalu menggunakan alat-alat itu untuk kepentingan rakyat pekerja seluruhnya. Jadi revolusi kaum proletar bertujuan untuk mengambil alih kekuasaan politik agar dapat mengambil alat-alat Negara dan membuat mereka berguna bagi kaum proletar sendiri.

Namun, pengalaman Komune paris (1871) menunjukkan bahwa alatalat politik yang ada pada Negara borjuis telah dirancang dan disusun khusus untuk penindasan. Semua alat yang bersifat elitis terpisah dari massa dan dengan demikian terasing dari mayoritas rakyat pekerja. Sebuah Negara rakyat pekerja tidak membutuhkan alat-alat yang tidak dapat dijangkau rakyatnya. Alat-alat Negara semacam ini justru akan menghambat kerja-kerja revolusioner dari rakyat pekerja di kemudian hari. Maka dari itu, Komune 
Paris membubarkan tentara regular untuk kemudian diganti dengan milisi (rakyat bersenjata). Perangkat perundangan pun diganti di mana setiap keputusan hukum harus disetujui lebih dahulu oleh komune sebelum dilaksanakan. Parlemen dibubarkan dan diganti oleh Dewan Rakyat, commune, yang memegang kekuasaan legislatif, yudikatif, dan eksekutif sekaligus. Anggota-anggota komune ini dipilih secara berjenjang. Seluruh anggota komune di tingkatan terkecil memilih langsung pemimpin mereka, para pemimpin dari tiap tingkatan untuk memilih dari tingkatan yang lebih tinggi dan seterusnya sampai tingkatang tertinggi.

Negara bagi Marx bukanlah sebuah satu gagasan, namun Negara adalah satu kenyataan yang mewujudakan dlaam satu peralatannya: peralatan represif bagi Negara penindas, peralatan demokratis bagi Negara Rakyat Pekerja. Bagi Marx, berbicara tentan Negara adalah sama dengan bicara tentang aparatur Negara dan kekuasaan politik berdiri di belakangnya.

Di sudut lain, Marx berpendapat bahwa hubungan antar kelas proletar dan borjuis kapitalis sangat bersifat eksploitatif dan antagonistic. Kelas proletar selalu dieksploitasi kelas borjuis-kapitalis. Keadaan ini melahirkan kondisi di mana kelas proletar merasa teralienasi dari lingkungan sosialnya sendiri. Tidak ada resep lain untuk terjadinya perubahan sosial melainkan revolusi menentang kaum borjuis. Pada saat melakukan itu, kelas proletar harus berusaha menghapus perbedaan-perbedaan kelas atau antagonism kelas. Pada akhirnya, revolusi proletar harus ditujukan pada penghapusan kelas. Bila ini terjadi di Negara yang menjadi alat penindas kaum borjuiskapitalis tanpa menghancurkan, akan lenyap dengan sendirinya.

\section{Negara menurut Lenin}

Lenin adalah pemimpin golongan Bolshevik dari partai Sosial Demokrat Rusia di tahun 1903. Selain golongan Bolshevik, partai ini juga 
memiliki golongan Menshevik. Golongan Menshevik adalah golongan yang setia pada ajaran Marx secara total dan menyeluruh. Bolshevik, golongan Lenin yang menghendaki perubahan-perubahan dalam teori Marx. Perbedaan ini terlihat pada dua hal. Pertama, dalam hal kepartaian. Menshevik berpendapat bahwa partai komunis harus berstruktur longgar dan berdasarkan pada masa (basis massa yang luas). Sebaliknya, Lenin beranggapan bahwa partai itu harus tersentralisasi, berdisiplin kuat dan terdiri dari revolusioner professional. Kedua, dalam hal memandang tahapan revolusi Marx. Menshevik percaya bahwa proletar harus menunggu revolusi borjuis terhadap feudal sebelum melakukan revolusi proletar terhadap borjuis. Pada masa itu Rusia masih dipimpim oleh kaisar. Lenin justru berpendapat hal itu akan melemahkan semangat proletar. Lenin ingin sebuah revolusi yang ditujukan untuk menjatuhkan borjuis sekaligus kaisar. Lenin juga menambahkan tentang peran penting petani dalam revolusi tersebut. Menurutnya, Marx kurang menekankan pentingnya peran petani dalam revolusi (mungkin Marx mendasar teorinya pada nasib buruh pasca revolusi Inggris). Kata lenin, revolusi yang dipimpin oleh kelas pekerja itu akan menghasilkan diktator demokrasi yang revolusioner dari proletar dan petani. ${ }^{8}$

Pada bulan Oktober 1917, lenin melakukan revolusi terhadap kaisar (feodal) bukan kepada borjuis dan tidak dibawah komando kaum borjuis. Revolusi ini berhasil menyingkirkan dua musuh proletar, yaitu kaum feudal dan borjuis. Namun kenyataannya setalah revolusi Rusia terlempar dalam kondisi situasi chaos. Roda perekonomian terhenti, dan jika tetap keras kepala tidak melibatkan borjuis dalam sistem ekonomi dan pemerintahan, Negara akan bangkrut. Oleh karena itu, pada tahun 1921 Lenin mulai melancarkan politik perekonomian baru. Perusahaan-perusahaan pribadi di

8. Deliar Noer, Pemikiran Politik di Negeri Barat., (Bandung: Pustaka Mizan, 2006), hlm. 218 
beberapa sector dibenarkan, dan orang-orang yang ahli di bidangnya kembali dipakai dengan bayaran besar. Menurutnya, Negara memerlukan orang-orang yang berpengalaman mengatur Negara dan ekonomi, dan orang-orang ini ada di kelas yang lama. Kita terpaksa dengan pertolongan kelas yang kita tumbangkan. Pada akhirnya, hilang sudah kesempatan proletar untuk belajar dari kaum borjuis. Hasilnya, ketika proletar sudah berkuasa, mereka justru memerlukan borjuis untuk membantu mereka dan bukannya memburu borjuis untuk dihabisi.

Di dalam buku State and Revolution. Ia menulis setelah revolusi 1917 di Rusia:

Negara adalah hasil dan perwujudan dari tidak terdamaikannya pertentangan kelas. Negara itu muncul ketika, di mana dan pada tingkatan itu secara obyektif pertentangan kelas tak dapat di damaikan (Lenin, 1918; 12).

Pandangan penting dari lenin adalah negara sebagai alat dari klas yang berkuasa, walaupun negara bertujuan mendamaikan pertentangan klas itu, namun konflik itu tetap tidak terdamaikan. Dalam interpretasi Lenin terhadap Marx. Keniscayaan munculnya negara justru karena konflik itu. Kata lenin selanjutnya :

Jika negara adalah hasil dari tak terdamaikannya pertentangan klas, jika ia adalah sesuatu kekuasaan yang berdiri di atas dan secara meningkat mengasingkan dirinya dari masyarakat maka....pembebasan klas tertindas adalah mustahil jika ia tanpa sebuah revolusi kekerasan, atau tanpa penghancuran aparatus kekuasaan negara yang telah diciptakan klas penguasa dan yang telah terwujudkan alienasi itu.

Jadi, penghancuran negara borjuis adalah esensial dalam setiap perubahan revolusioner. Penghancuran itu di lakukan melalui konfrontasi 
bersenjata, karena negara adalah kekuatan bersenjata dari borjuasi. Intinya di sini adalah seluruh lembaga 'demoktatik' dalam masyarakat kapitalis dikontrol secara langsung klas borjuis, dan fungsi utamanya adalah mengarahkan kekerasan. Dengan menghantam kekuatan koersif ini langsung di jantungnya dan menghancurkan senjata utamanya, negara borjuis akan hancur, instrumen penindasan dengan demikian akan terlucuti, dan kaum proletar mengambil alih kekuasaan, menggunakannya dengan kekuatan bersenjatanya sendiri untuk melindungi kekuasaan itu.

Tujuan utama lenin dalam State and Revolution agaknya bukan ditujukan untuk menjelaskan hakikat negara burjuis semata. Namun ia berupaya menjelaskan sesuatu strategi khusus bagi revolusi sosialis. Strategi itu mempunyai dua bagian. Pertama menggulingkan negara borjuis. Kedua, transisi ke sosialisme.

Untuk strategi kedua ini, transisi ke sosialisme, lenin menjelaskan lebih jauh. Doktrin perjuangan klas itu tidaklah diciptakan oleh Marx, namun oleh kaum borjuis sebelum Marx, dan secara umum ia dapat diterima oleh kaum borjuis..seseorang di sebut sebagai marxis jika ia meluaskan pengetahuannya tentang kediktatoran ploretar.

Maknanya adalah, perjuangan klas terus berlanjut dalam transisi dari kapitalisme ke komunisme, dan karena negara tetap dibutuhkan untuk mengeliminasi klas borjuis. Karena negara sebelumnya adalah alat kediktatoran kaum borjuis, maka ia harus diganti dengan kediktatoran ploretariat. Soalnya, Lenin meramal bahwa kaum borjuis pasti akan memberikan reaksinya. Dari sudut klas pekerja, kapitalis memang tidak penting lagi bagi mereka setelah revolusi. Namun bagi kaum borjuis, revolusi berarti berakhirnya seluruh posisi istimewa mereka, dan hanya ada alternatif bahwa mereka akan menjadi buruh biasa dalam sistem sosialisme. Dengan begitu, mereka akann habis-habisa menyerang rezim yang baru denagn segala 
apa yang tersisa pada mereka. Jadi bagi Lenin kediktatoran borjuis akan digantikan oleh kediktatoran ploretar selama periode transisi dari kapitalisme ke komunisme.

Lalu apakah makna dari ucapan Engels bahwa dibawah sosialisme negara akan melenyap? Lenin mendiskusikan hal ini dengan detail yang khusus. Beberapa konsep Lenin yang menginduk pada Engels. Namun dalam hal ini di kutip dari beberapa hal penting yang di tulis Lenin dalam State and Revolution.

Pernyataan itu bagi Lenin sebenarnya berkisar tentang penghapusan negara borjuis oleh sebuah revolusi ploretar. Melenyapnya negara dapat diartikan bentukk sisa-sisa ketatanegaraan ploretar sesudah revoolusi sosialis. Negara borjuis memang tidaklah melenyap, melainkan dihapus oleh ploretariat dalam revolusi.

Menurut Lenin Negara merupakan sebuah kekuatan penindas yang khusus, yang dalam masyarakat kapitalis digunakan menindas ploretariat, maka kekuatan itu harus diganti dengan kekuatan penindas khusus dari ploretariat terhadap borjuis. Inilah yang kemudian disebut dengan penghancuran 'Negara sebagai Negara' pengambil alihan alat-alat produksi atas nama masyarakaat. Namun proses ini belum berarti negara melenyap, ia baru digantikan oleh satu satuan khusus saja.

Kemudian melenyapnya negara adalah masa dimana zaman sesudah dimilikinya alat-alat produksi oleh negara atas nama seluruh rakyat, yaitu sesudah revolusi sosialis. Pada tahap inilah terjadi demokrasi sepenuhpenuhnya. Ketika negara melenyap maka otomatis demokrasi sepenuh juga melenyap. Karena, menurut Lenin demokrasi juga bagian dari negara. Dengan logika demikian, jika negara melenyap maka demokrasi tidak dibutuhkan lagi. 
Demikian, secara singkat beberapa hal penting yentang negara dalam pemikiran Marxisme. Paparan diatas menyimpulkan bahwa, negara bagi Marxisme alat bagi klas yang berkuasa untuk melakukan penindasan kepada warga masyarakat. Sebagai alat dari kaum borjuasi dalam sistem kapitalis, kekuasaan negara diabdikan untuk kepentingan klas ini, seperti juga halnya negara yang mengabdikan kekuasaanya kaum bangsawan dalam sisitem feodal. Kaum Marxis karena itu lebih memusatkan perhatiannya pada studi tentang klas sosial yang ada dalam masyarakat, khususnya klas dominan, dan bagaimana klas dominan itu melakukan manipulasi kekuasaan negara untuk kepentingan dirinya.

Analisa tentang negara ini sangat penting dalam membangun strategi perubahan radikal (revolusi), yang diyakini kaum Marxis sebagai upaya pembebasan manusia atas setiap proses penindasan yang menimpanya. Kaum buruh (Ploretar) diyakini mengemban tugas perubahan revolusioner ini, karena ia adalah klas yang dirugikan dalam sistem kapitalisme. Naamun garis besar penyimpulan ini bukanlah berarti sebuah simplifikasi. Ada beberapa persoalan pelik manakala penyimpulan ini hendak diterapkan pada situasisituasi yang khusus.

\section{Negara menurut Stalin}

Stalin memimpin Uni Soviet semenjak 1924, memiliki pemikiran yang lebih maju dari Lenin. Stalin tidak menunggu buru-buru Negara lain melakukan revolusi, Stain mendorong terjadinya sosialisme di dunia. Misalnya, menyetujui Partai Komunis Indonesia (PKI) untuk memberontak kepada pemerintah Belanda pada 1926-1927. Pemberontakan ini sebenarnya ditentang oleh Tan Malaka karena ia merasa persiapan belum cukup matang. Stalin melakukan intervensi terhadap Mao Zedong melalui Maring 
(sebelumnya bernama Sneevliet, bergerak di Indonesia) dengan memerintah Mao untuk bekerja sama dengan Chiang Kai Sek dari Partai Kuomintang. ${ }^{9}$

Stalin memperkenalkan model perencanaan lima tahun. Model ini dirancang untuk menjadikan Uni Soviet sebagai kekuatan industri dan militer. Model iilah yang kemungkinan ditiru oleh Soeharto sebagai Rencana Pembangunan Lima Tahun (Repelita). ${ }^{10}$ Jika benar Soeharto terinspirasi dari Stalin maka ini sebuah ironi, karena Soeharto mengambil contoh dari sebuah Negara komunis, yang ideologinya dilarang untuk berada di Indonesia semenjak masanya. Ini pun sekaligus menunjukkan bahwa sebuah orde yang begitu membenci komunisme pun bisa memetik pelajaran darinya, sehingga kekuatan berlebihan terhadap komunisme akan menutup kemungkinan bangsa ini untuk mengambil hal-hal baik dari komunisme.

\section{Kesimpulan}

Masihkah kita mengimani Negara sebagai tujuan akhir yang sama seperti Roh Kudus yang menjelma sebagai derap langkah Tuhan di bumi?

\section{Daftar Pustaka}

Marx, Karl, Das Kapital

\section{Marx, Karl, Manifesto Komunis}

Kristeva, Nur Sayyid Santoso, Negara Marxis dan Negara Proletar., (Yogyakarta: Pustaka Pelajar, 2015)

Brown, Strurt Gerry, State, dalam Encyclopedy International., (New York: Glorier, 1970)

\footnotetext{
9 Ibid., hlm. 231

10. Repelita adalah Rencana Pembangunan Ekonomi Indonesia. Repelita I dimulai tahun 1969-1973 dengan menekankan program memperkuat ketahanan pangan dasar dan infrastruktur. Sedangkan Repelita terakhir (sebelum Orde Baru tumbang) adalah Repelita V dimulai tahun 1989-1993 yang bertujuan untuk memperkuat bidang transportasi, komunikasi, dan pendidikan.
} 
Fink, Hans, Filsafat Sosial, Dari Feodalis Hingga Pasar Bebas, diterjemahkan dari judul asli:Social Philosophy, Methuen \& Co. Ltd, London dan Methuen \& Co. New York, 1981, Penerjemah: Sigit Djatmiko, (Yogyakarta: Pustaka Pelajar, Cet. I, 2003

Hegel, G.W.F., Filsafat Sejarah, judul asli: The Philosophy of History, Penerjemah: Cuk Ananta Wijaya (Yogyakarta: Pustaka Pelajar, Cet. III, 2007)

Sztompka, Piotr, Sosiologi Perubahan Sosial., Judul Asli: The Sociology of Social Change, Penerjemah: Alimandan (Jakarta: prenada, Cet. III, 2007)

Slater, Phil, Origin and Signifance of The Frankfurt Schoo;, A Marxis Perspective., (London: Routledge \& Kegan Paul, 1977)

Suhelmi, Ahmad, Pemikiran Politik Barat: Kajian Sejarah Perkembangan Negara, Masyarakat dan Kekuasaan., (Jakarta: Gramedia Pustaka Utama, 2001)

Hacker, Andrew, Political Theory, Philosophy, Ideology, Science., (New York: The Mcmillan, 1969)

Pelcynski, Hegel's Political Philosophy, Problems and Perspective, (Cambridge University Press, 1971)

Fukuyama, Francis, The End of History and The Last Man, (New York: Free Press, 1992)

Gerth, H.H \& C. Wright Mills (ed.) (1958), From Marx Weber Essays Individu Sociology, (New York: Oxford University Press)

C.C. Rodee, et.al., Pengantar Ilmu Politik., (Jakarta: Raja Grafindo Perkasa, 2000)

Noer, Deliar, Pemikiran Politik di Negeri Barat., (Bandung: Pustaka Mizan, 2006) 